\title{
Apparent nutrient digestibility of broiler starter fed varying levels of processed taro cocoyam (Colocasia esculenta) meal based diet \\ ${ }^{1}$ Ajetunmobi, A.W., ${ }^{2}$ Eguaoje, S. A., ${ }^{3}$ Adeniji, C. A., ${ }^{4}$ Omesa, M. T. and ${ }^{2}$ Iwegbu, A. ${ }^{1}$ Adeniran Ogunsanya college of Education, Ijanikin, \\ ${ }^{3}$ School of Agriculture, Lagos State University, Epe, Lagos, \\ ${ }^{4}$ Devine Fisheries farm estate, 12 Junction Ring Road, \\ Redemption Camp Ogun State.
}

${ }^{2} *$ Corresponding author: eguaojeabiodunstanley@gmail.com; 07031677645

\section{Abstract}

A ten-week feeding trial was conducted to evaluate the apparent nutrient digestibility of 120 , one-day old broiler starter chicks fed varying levels of Parboiled sundried taro cocoyam (Colocasia esculenta) meal (PSCM). Four treatments were formulated with diet one containing 100\% maize as control, while in diet two, three and four parboiled sundried cocoyam meal (PSCM) replaced the percentage proportion of maize in diet one at 50, 75 and $100 \%$ inclusion levels respectively. Thirty (30) birds were randomly assigned to the four treatment diets in a complete randomized designed (CRD) and each treatment group contained three replicates with ten (10) birds each. Ground fed feed and voided faecal samples collected after a 4-day feeding in a metabolic cage were analyzed for their respective proximate constituent. Apparent nutrient digestibility revealed that crude fibre was significantly $(P<0.05)$ higher in diet 4 while crude ash was significantly $(P<0.05)$ higher in control. Digestible ether extract and NFE were significantly $(P<0.05)$ higher among birds placed on 50\% PSCM. It is therefore concluded that parboiled sundried taro cocoyam meal (PSCM) could replace 50\% of maize in broiler starter diet without any deleterious effect. However, substituting maize with parboiled sundried taro cocoyam meal at 50\% replacement level improved nutrient digestibility and is hereby recommended for poultry farmers.

Keywords: Broiler Starter, Taro Cocoyam, Nutrient digestibility, Parboiled-Sundried

\section{Introduction}

Inadequate poultry and livestock feed supply and nutrition had been identified as the major constraint to poultry and livestock production in Nigeria. This is so because the conventional livestock feedstuffs sources have been very expensive especially in monogastrics diets. However, the search for locally available feedstuffs that can substitute these conventional energy/ protein feed ingredients at cheap cost is imperative. The need to boost animal production to produce the much needed protein for the ever increasing human population in the developing countries cannot be over emphasized. (FAO, 2007). Recently, effort has been geared towards the use of unconventional feed stuff such as agroindustrial by products and root tubers like yam, cocoyam etc. that may bring about the expected reduction in livestock feed cost and consequently poultry or livestock products (Aderemi, 2003). Several reseachers have reported their success stories on the use of unconventional feed ingredients. Okosun and Eguaoje, (2017) also reported that Cassava grit at $66.6 \%$ level of inclusion with $5 \%$ moringa leaf meal supplementation resulted in better biological performance in cockerel chickens. Omoikhoje (2004) reported that cooked Bambara groundnut meal was not nutritionally inferior to groundnut cake diet 
and can quantitatively replace groundnut cake up to $10 \%$ level of inclusion without any adverse effect on broiler chickens due to the level of aldosterol in cooked Bambara groundnut meal. Ehebha and Eguaoje, (2018) reported that sundried cassava peel can be included up to $20 \%$ in broiler chickens diet without any deleterious effect on the performance of the birds. Anigbogu (1997) reported that taro meal should not exceed $25 \%$ replacement of maize in broiler diets. Consequently, this present study is focused on the use of cocoyam meal as basal diet in poultry diet. The use of cocoyam as food for man and animal has limiting factors such as storage and presence of antinutritional factors such as oxalates, phytates, tannins and saponins. (Agwunobi et al., 2002). There is limited reference work on the utilization and inclusion of taro cocoyam as an alternative energy source in poultry production. However, this present study is therefore aimed at evaluating the apparent nutrient digestibility of starting broiler fed graded levels of parboiled sundried taro cocoyam meal based diet.

Materials and methods

\section{Location and duration of the experiment}

The research was conducted at the poultry unit of the Livestock Teaching and
Research Farm of Agricultural Science Education Department, Adeniran Ogunsanya College of Education, Oto/Ijanikin, Lagos State, Nigeria for the period of ten weeks.

Sourcing and processing of the raw materials The unpeeled Taro cocoyam cormel used for the feeding trial was purchased from local market in Ijanikin, Lagos, Nigeria and thereby village market. It was then chopped into aliquots of about $1 \mathrm{~mm}$ and parboiled for about $15 \mathrm{mins}$ then drained of water and was air dried overnight then later sundried for 7-14 days to reduce the moisture content to about $10 \%$ or less. The parboiledsundried Taro cocoyam and other feed ingredients were milled separately and to formulate the experimental diet. Sample was taken from the processed Taro cocoyam and was kept in an airtight polythene bag and taken to the laboratory for proximate analysis.

Chemical analysis of the processed raw material

The moisture content, ash, crude fibre and crude fat, were determined using the method described by AOAC (1990). The crude protein was also determined by Kjeldahl method while energy value was determined using an Adiabatic Oxygen Bomb calorimeter (12149) Adiabatic calorimeter, PARR instrument Co. Illinois USA. The result is presented in Table 1 .

Table 1: Proximate composition of taro cocoyam and maize

\begin{tabular}{lll}
\hline Components & PSCM & Maize \\
\hline Dry matter & 87.62 & 89.80 \\
Crude protein & 7.87 & 8.94 \\
Crude fibre & 4.75 & 2.76 \\
Ether extract & 0.76 & 4.34 \\
Crude ash & 6.05 & 2.01 \\
NFE & 68.37 & 71.75 \\
Carbohydrate & 45.06 & 26.54 \\
ME (Kcal/kg) & 3214.91 & 3325.42 \\
\hline
\end{tabular}

*Analyzed; PSCM: Parboiled sundried Cocoyam meal 


\section{Experimental animals, design and management}

One hundred and twenty (120) one-day old ANAK 2000 broiler chicks were purchased from a reputable hatchery in Ibadan south west Nigeria. The design of the experiment was a completely randomized design (CRD) comprising of four (4) treatment diets with treatment one being the control with $100 \%$ inclusion level of maize and $0 \%$ parboiled sundried taro cocoyam meal (PSCM) while diets 2, 3 and 4 had inclusion levels of parboiled sundried Taro cocoyam meeal (PSCM) at 50, 75 and 100\% respectively. Each treatment diets had thirty birds of ten birds per replicate. Experimental birds were fed commercial diet for the first two weeks during brooding. All animals were allowed assess to feed and clean drinking water ad-libitum and routine medication and vaccination was adhered to. All the diets (1 to 4 ) were formulated to be isonitrogenous $(21 \%)$ and isocaloric (2890 ME Kcal/kg) as reflected in Table 2

Table 2: Percentage composition of broiler starter diets

\begin{tabular}{lllll}
\hline & \multicolumn{4}{c}{ Inclusion levels of PSCM (\%) } \\
\cline { 2 - 5 } & 0 & 50 & 75 & 100 \\
\hline Maize & 48.00 & 24.00 & 12.00 & 0.00 \\
PSCM & 0.00 & 24.00 & 36.00 & 48.00 \\
Soya bean meal & 35.00 & 35.00 & 35.00 & 35.00 \\
Wheat offal & 7.50 & 7.50 & 7.50 & 7.50 \\
Fish meal & 5.00 & 5.00 & 5.00 & 5.00 \\
Dicalcium phosphate & 2.50 & 2.50 & 2.50 & 2.50 \\
Palm oil & 1.00 & 1.00 & 1.00 & 1.00 \\
Premix & 0.50 & 0.50 & 0.50 & 0.50 \\
Salt & 0.50 & 0.50 & 0.50 & 0.50 \\
Total & 100.00 & 100.00 & 100.00 & 100.00 \\
Calculated analysis & & & & \\
Crude protein & 21.03 & 21.02 & 21.04 & 21.09 \\
ME (Kcal/kg) & 2885.00 & 2875.00 & 2892.00 & 2880.00 \\
\hline
\end{tabular}

Apparent digestibility of nutrients

At the expiration of the experiment, two birds per replicate were randomly selected and housed individually in a metabolic cage. A 5-day acclimatization period were allowed prior to a 4-day collection period; thereafter the birds were fed the specific quantities of the treatment diets. Daily excreta voided per bird were collected and dried over night at $60^{\circ} \mathrm{c}$ for 12 hours and kept frozen $\left(-20^{\circ} \mathrm{C}\right)$ until it's ready for analysis. Prior to analysis, Excreta sample was dried at $65^{\circ} \mathrm{C}$ in an air-tight oven to a constant weight and ground through a $1 \mathrm{~mm}$ screen for proximate analysis. Ground fed feed and voided faecal samples were analyzed for their respective proximate constituent. (AOAC 1990). Apparent digestibility of dry matter, crude protein, crude fibre, ether extract, ash and Nitrogen free extract were estimated using the formular below.

Apparent nutrient digestibility $=$

$\frac{\text { Nutrient in feed-Nutrient in feaces }}{\text { Nutrient in feed }} \times \frac{100}{1}$

\section{Statistical analysis}

All data were subjected to a one-way analysis of variance (ANOVA) and differences between means and treatments were seperated using Duncan's multiple range test (DMRT) at 5 percent level of 


\section{Apparent nutrient digestibility of broiler starter fed varying levels of processed taro cocoyam}

probability. All statistical procedures were according to (Steel and Torrie, 1990) with the aid of SAS 1999 package.

\section{Results}

Table 3 revealed that the varying levels of parboiled sundried taro cocoyam meal (PSCM) has no significant $(\mathrm{P}>0.05)$ effect on the apparent digestible dry matter content and crude protein content but a significant $(\mathrm{P}<0.05)$ variation was observed for crude fibre, ether extract, crude ash and Nitrogen free extract (NFE) of the treatment diets. Dry matter and crude protein content were statistically similar $(\mathrm{P}>0.05)$ among broiler chickens fed the treatment diets with highest numerical values recorded from chickens on 50\% PSCM based diets. Apparent digestible crude fibre was significantly $(\mathrm{P}<0.05)$ highest with an average value of $70.03 \%$ in chickens fed $100 \%$ PSCM, followed by $68.33 \%$ from those on $75 \%$ PSCM comparable to $65.21 \%$ from those on $50 \%$ PSCM while lowest value of $61.26 \%$ was recorded in broiler chickens on the control. Apparent digestible ether extract was significantly $(\mathrm{P}<0.05)$ highest with an average value of $85.26 \%$ in birds fed $0 \%$ PSCM, compared to $84.62 \%$ to those in $50 \%$ PSCM while lowest value of $76.44 \%$ was recorded in birds on $100 \%$ PSCM. Apparent digestible crude ash was significantly $(\mathrm{P}<0.05)$ with highest value of $49.83 \%$ in birds fed $50 \%$ PSCM, followed by $47.44 \%$ from those fed the control diet while lowest value of $43.63 \%$ was recorded in broiler chickens fed $75 \%$ PSCM. Nitrogen free extract value was also significantly $(\mathrm{P}<0.05)$ higher among birds fed 50\% PSCM with an average value of $57.16 \%$, followed by $52.44 \%$ from those on $100 \%$ PSCM while lowest value of $50.63 \%$ was recorded in chickens fed the control diet.

Table 3: Apparent $\mathbf{n}$ utrient digestibility of broiler chickens fed parboiled sundried cocoyam meal

\begin{tabular}{lccccc}
\hline Parameters & 0 & 50 & 75 & 100 & SEM \pm \\
\hline App. Digestible dry matter & 66.40 & 67.21 & 66.52 & 66.83 & 0.32 \\
App. Digestible crude protein & 54.26 & 55.80 & 54.64 & 54.26 & 0.45 \\
App. Digestible crude fibre & $61.26^{\mathrm{c}}$ & $65.21^{\mathrm{b}}$ & $68.33^{\mathrm{b}}$ & $70.03^{\mathrm{a}}$ & 6.25 \\
App. Digestible crude ash & $85.26^{\mathrm{a}}$ & $84.62^{\mathrm{a}}$ & $78.43^{\mathrm{b}}$ & $76.44 \mathrm{c}$ & 5.36 \\
App. Digestible ether extract & $47.44^{\mathrm{ab}}$ & $49.83^{\mathrm{a}}$ & $42.63^{\mathrm{c}}$ & $46.26 \mathrm{~b}$ & 3.30 \\
App. Digestible NFE & $50.63^{\mathrm{d}}$ & $57.16^{\mathrm{a}}$ & $51.26^{\mathrm{c}}$ & $52.44 \mathrm{~b}$ & 7.32 \\
\hline
\end{tabular}

abc: means in the same row with varying super script differ significantly $(\mathrm{P}<0.05)$

\section{Discussion}

High dry matter content though not significant corroborate the report of Longe and Ogedengbe (1999) that diluting diet with fibre sources contributes largely to the bulkiness of the resultant diet. This is also in tandem with the report of Eguaoje and Okosun (2017) that there was no significant difference in the dry matter content of the birds fed cassava grit supplemented with moringa leaf meal. The insignificant $(\mathrm{P}>0.05)$ variation in the apparent digestible crude protein among the treatment diet may be due to high quality of the diet as apparent crude protein digestibility has been reported to depend on the source and concentration of the protein in the feed stuff (Mc Donald et al., 1991). However, this finding negates the report of Aguihe et al. (2015) on significant variation in the digestible crude protein of broiler chickens fed cassava peel meal based diet with enzyme Maxigrain ${ }^{\circledR}$ supplementation. The highest digestible crude fibre recorded among birds fed $100 \%$ parboiled sundried taro cocoyam meal could be as a result of the high fibre content of the basal diet as cocoyam is known to be high in fibre (Apata and Babalola, 2012).

Aguihe et al. (2015) similarly reported a 


\section{Ajetunmobi, Eguaoje, Adeniji, Omesa and Iwegbu}

significant variation in the digestible crude fibre of broiler chickens fed cassava peel meal based diet with enzyme Maxigrain ${ }^{\circledR}$ supplementation. Higher ash content recorded in the control compared to those on $50 \%$ PSCM may be attributed to the presence of minerals, indicating that PSCM may be a potential source of minerals. This observation agreed with Gernah et al. (2007) that Locust bean pulp (LBP) was a good source of minerals required by the body. The significant variation in the ether extract content with higher value recorded among birds on $50 \%$ PSCM compared to those on control could be due to the high energy value of the basal diet and maize. The improvement in apparent digestibility of NFE recorded among birds placed on $50 \%$ PSCM may be due to the high energy content of the dietary treatment which agreed with the report of earlier authors (Aderemi 2007; Aguihe et al., 2017; Eguaoje and Okosun, 2017).

\section{Conclusion}

It is therefore concluded that parboiled sundried taro cocoyam meal (PSCM) could replace $50 \%$ of maize in broiler starter diet without any deleterious effect. However, substituting maize with parboiled sundried taro cocoyam meal at 50\% replacement level improved nutrient digestibility and is hereby recommended for poultry farmers.

\section{References}

Aderemi, F. A., Lawal, T. E. and Iyayi, E. A. 2007. Nutritional value of cassava root sieviate and its utilization by layers. African Journal of Food Technology: 4 (3): 216-220.

Aderemi, F. A. 2003. Effect of Enzyme supplemented cassava root sievate (CRS) in cassava based diet on some visceral organ of pullet chucks. In: Olatunji E.A; Ayan Wale, B.A; Shiawoya, E.L. and Aremu, A (Editors). Proceedings of $8^{\text {th }}$ Annual conference of Animal Science Association of Nigeria, Minna, Nigeria September 2003, Pp. 25-27.

Aguihe, P. C., Kehinde, A. S., Babatunde, T. O. and Iyayi, E. A. 2015. Effect of supplementation of cassava peel meal based diet with enzyme Maxigrain ${ }^{\circledR}$ on performance, apparent nutrient digestibility and economic indices of broiler finishers. Nigerian Journal of Animal Production. 42:(1) 65-72

Agwunobi, L. N., Angwukam, P. O., Cora, O. O. and Isika, M. A. 2002. "Studies on the use of Coweosia esculenta (Taro cocoy am) in the diets of weaned pigs" Tropical Animal Health and Production 34: 244 - 47. cassava" A.I.D. csd/2497. Univ. of Georgia, p p 325, 1972

Anigbogu, N. M. 1996. Economic costs of using taro (Colocasia esculenta Linn). In broiler rations. ITTA Tropical Root and Tuber Crops Bulletin, 9(1): 8-10.

A. O. A. C. (Association of Official Analytical Chemists) 1990. Official Methods of Analysis of the AOAC international.16 ${ }^{\text {th }}$ ed 4 th revised method 944.02. The Association, Gaithersburg, MD.

Apata, D. F. and Babalola, T. O. 2012. The Use of Cassava, Sweet Potato and Cocoyam, and Their By-Products by Non - Ruminants. International Journal of Food Science and Nutrition Engineering. 2(4): 54-62

Eguaoje, S. A. and Okosun, S. E. 2017. Cassava grit and moringa leaf meal utilization in poultry nutrition. Lambert Academic publishing. Pp: 
82

Ehebha, E. T. E. and Eguaoje, A. S. 2018.

Grow th Performance Characteristics of Broiler Chickens Fed Graded Levels of Sundried Cassava (Manihot esculenta) Peel Meal Based Diet. Asian Journal of Advances in Agricultural Research 6(4): 1-7, 2018

F. A. O. 2007. http://faostat.fao.org. Agricultural Statistics. Food and Agricultural Organization of the United nations. Rome

Gernah, D. I., Atolagbe, M. O. and Echegwo, C. C. 2007. Nutritional Composition of the African Locust Bean (Parkia biglobosa) fruit pulp. Nigerian Food Journal. 25 (1): 190 $-196$.

Longe, G. O. and Ogedengbe, N. E. 1999. Influence of fibre on metabaolizable energy of diets and performance of growing pullets in the Tropics. British Poultry Science 30;193-195

Madubuike, F. N. and Ekeyem, B. U. 2006. haematology and Serum biochemistry characteristics of broiler chicks fed varying dietary levels of Ipomea asarifolia leaf meal. Int. J. Poult. Sci., 5: 9-12
McDonald, P., Edward, R. A. and Greenhalgh, H. 1991. Evaluation of food in: Animal nutrition $\left(4^{\text {th }}\right.$ Edn) Longman Scientific and technical. England Pp 260-283.

Obidinma, V. N. 2009. Brewer's spent grain as energy source in finisher broiler birds and laying hen production. $\mathrm{PhD}$. Thesis, Imo State University, Owerri, Nigeria

Omoikhoje, S. O. 2004. Effect of processing on the biochemical nutritional qualities and some antinutrient. Components of Bambara groundnut (Vigna subterranea) fed to broilers. PHD thesis, Department of Animal Science, Ambrose Alli University. Nigeria.

SAS 1999. SAS Users Guide Statistics. SAS Institute Cary, North Carolima, USA.

Smith, D. L. 1982. Calcium Oxalate and Carbonate Deposits in Plant Cells. In: The Role of Calcium in Biological Systems, Anghileri, L.J. and A.M. Tuffet-Anghileri (Eds.). CRC Press, Florida, USA., pp: 253-226.

Steel, R. G. D. and Torrie, J. H. 1990. Principle and procedure of statistics. A Biometrical Approach 3rd Edition. MacGraw Hill Book. Co. New York.

Received: $4^{\text {th }}$ July, 2019 Accepted: $18^{\text {th }}$ December, 2019 